\title{
THE IMPACT OF TEAM-MEMBER EXCHANGE ON THE INTRA-TEAM KNOWLEDGE SHARING: THE ROLE OF INTRA-TEAM TRUST AND PSYCHOLOGICAL OWNERSHIP*
}

\section{Yavuz Selim DÜGER ${ }^{1}$}

\begin{abstract}
In the globalising world, knowledge is accepted as the most important source of competition. Ownership and effective management of knowledge by the businesses are of great importance in terms of maintaining their existence. In this context, knowledge sharing by the employees with the organisation is of vital importance for the success of the businesses and it is also a moral responsibility. Significant responsibilities fall upon managers and team members with relation to share of knowledge owned by the employees. In this study, it has been aimed to measure the impact of team-member exchange on intra-team knowledge sharing process and to discover empirically the roles of intra-team trust and psychological ownership in such relation. In this line, data have been collected from 179 employees (29 teams) of an establishment operating in various sectors in Istanbul. According to the results of the research, teammember exchange has positive impact on intra-team knowledge sharing process. Moreover, intra-team trust and psychological ownership have positive impact on intra-team knowledge sharing and they have a moderating role in the relation between team-member exchange and intra-team knowledge sharing.

Keywords: Team-Member Exchange, Intra-Team Knowledge Sharing, Intra-Team Trust, Psychological Ownership JEL Codes: M10, M50, O15
\end{abstract}

\section{TAKIM-ÜYE DEĞIŞ̧iMININ TAKIM İÇi BİLGİ PAYLAŞIMINA ETKİSi: TAKIM İÇí GÜVEN VE PSIKKOLOJIK SAHIPLENMENIN ROLÜ}

$\ddot{O} \mathbf{z}$

Küreselleşen dünyada, bilgi rekabetin en önemli kaynağı olarak kabul edilmektedir. İşletmelerin bilgiye sahip olması ve etkin bir şekilde yönetebilmesi, varlığını devam ettirebilmesi açısından son derece önemlidir. Bu bağlamda, çalı̧̧anların sahip olduğu bilgiyi örgüt ile paylaşması, işletmenin başarısı için hayati öneme sahip olmakla birlikte, aynı zamanda ahlaki bir sorumluluğudur. Çalışanların sahip olduğu bilgiyi paylaşması noktasında yöneticilere ve takım üyelerine büyük görev düşmektedir. Bu çalışmada, takım-üye değişiminin, takım içi bilgi paylaşımına olan etkisini ölçmek ve bu ilişkide ampirik olarak takım içi güven ve psikolojik sahiplenmenin rolünü keşfetmek amaçlanmaktadır. Bu doğrultuda, İstanbul'da çeşitli sektörlerde faaliyet gösteren bir işletmenin 179 çalışanından (29 takım) veriler toplanmıştır. Araştırma sonucuna göre, takım-üye değişiminin takım içi bilgi paylaşımına olumlu etkisi bulunmaktadır. Ayrıca, takım içi güven ve psikolojik sahiplenmenin takım içi bilgi paylaşımına olumlu etkisi bulunmakta ve takım-üye değişimi ve takım içi bilgi paylaşımı arasındaki ilişkide moderatör rolü bulunmaktadır. Anahtar Kelimeler: Takım-Üye Değişimi, Takım İçi Bilgi Paylaşımı, Takım İçi Güven, Psikolojik Sahiplenme JEL Kodları: M10, M50, O15

\footnotetext{
*This article was decided that it is ethically appropriate by Kütahya Dumlupinar University Social and Human Sciences Scientific Research and Publication Ethics Committee, dated 21.05.2020 and numbered 2020/05.

${ }^{1}$ Assist. Prof. Dr., Kütahya Dumlupinar University, Faculty of Economics and Administrative Sciences, Department of International Trade and Finance, yselim.duger@dpu.edu.tr, ORCID: 0000-0003-3523-9671.

Başvuru Tarihi (Received): 02.05.2021 Kabul Tarihi (Accepted): 29.07.2021
} 


\section{Introduction}

Besides the capital owned by the businesses, knowledge potential is considered as a significant source of competition under today's conditions. Therefore, it is accepted as a highly strategic asset especially for the establishments (Cabrera, Collins and Salgado, 2006). Organizational knowledge is valuable and difficult to imitate and substitute. The ability of an organization to use the knowledge effectively largely depends upon its employees' creating, sharing and using such knowledge (Ipe, 2003). In this context, sharing of the knowledge owned by the employees and transferring it into the organization not only provide competitive advantage for the establishments but also make them acquire a fundamental ability to achieve organizational targets.

Today, the companies make for team-based administrative approaches in order to cope with intense competitive conditions (Chae, Seo and Lee, 2015). Teamwork depends upon the fact that individuals working interdependently obtain a performance far beyond the abilities of employees working independently, when they act collectively (DeOrtentiis, Summers, Ammeter, Douglas and Ferris, 2013). In this context, it is clearly seen that an effective teamwork makes great contributions to the organizations. Furthermore, display of harmonization and teamwork ability by the employees contributes to achievement of organizational targets (Love and Forret, 2008).

It is understood much better day by day that efficacy and performance of the organizations depend upon well sharing of the knowledge among individuals, teams and units (Liu, Keller and Shih, 2011). Many studies have been made with relation to the importance of knowledge sharing in organisations; however, there is limited number of studies with relation to the processes used to define, gather, share and use the knowledge in the organisation (Ipe, 2003). In this scope, it is of great importance that the grounds of the behaviour of knowledge sharing between an individual and team members should be comprehended.

Researches made on mutual exchange in organizations generally focus on the relation between the leader and the employee (Dansereau, Graen and Haga, 1975; Graen and Uhl-Bien, 1995). Such approach called as leader-member exchange has been searched intensely within the framework of social exchange theory. This approach has made significant contribution to the comprehension of the nature and characteristics of the exchange between the leader and employees. However, there is no sufficient number of studies with relation to determination of the quality, nature and characteristics of the exchange between team members. In addition, today the transformation of organization structures from vertical to horizontal day by day results in prominence of horizontal role relation between team members. Such situation results in the change of direction of focus of researches from leader-member exchange towards team-member exchange (Ghosh, Bharadwaja, Yadav and Kabra, 2019).

Trust has a very significant role in identification of team dynamics. Moreover, trust affects decision of individuals for making contribution, and provides organisation of powerful teamwork (Yang, 2014). Creation of high-level trust among the employees makes it possible to interpret the behaviours of team members positively and results in formation of customized group identity (Han and Harms, 2010). In addition, trust can support cooperation between employees, team satisfaction, team commitment and task performance (Costa, 2003). On the other hand, low level of trust among the employees may prevent effective fulfilment of team tasks (Fan, Suo, Feng and Liu, 2011).

The sense of ownership springing to the minds of individuals as a result of "mine" or "ours" perception is defined as psychological ownership (Van Dyne and Pierce, 2004). Psychological ownership positively affects the attitudes and behaviours of the employees, makes significant contribution to the performance of the organisation, and ensures adoption of the work and the organisation by the employees and display of more effort for the benefit of the organisation. Moreover, positive feelings adopted by the employees towards the organisation trigger their 
internal motivation and can make them display extra role behaviours such as knowledge sharing. In other words, the possibility of the employees with high-level psychological ownership to share knowledge with other employees in order to contribute to the organisation can be higher (Li, Yuan, Ning and Li-Yinget, 2015).

In this context, it is thought that examination of team-member exchange as the antecedent of knowledge sharing and discovery of the role of trust and psychological ownership in such relation will provide contribution to the literature. In this study, it has been firstly aimed to examine the relation between team-member exchange and intra-team knowledge sharing. Secondly, it has aimed to determine the impact of intra-team trust and psychological ownership on intra-team knowledge sharing. Finally, it has been aimed to put forward empirically the role of intra-team trust and psychological ownership in strengthening the relation between team-member exchange and intra-team knowledge sharing.

\section{Theoretical Background}

\subsection{Team-Member Exchange and Intra-Team Knowledge Sharing}

Team-leader exchange appearing as an extension of leader-member exchange is an approach putting forward the quality of the relation between team members (Seers, 1989). Leader-member exchange depends upon mutual relations and exchange between leader and employees. It reflects the vertical exchange relation between the leader and the employees. It also focuses on the differences occurring in leadership approaches due to the quality of the exchange (Dansereau et al., 1975). Team-member exchange, on the other hand, highlights the quality of the exchange between the individuals included in the team. It reflects the quality of the horizontal exchange within the team. It also focuses on perception of the roles within the team by means of intra-team commitment and harmonisation, and an efficient team work. Team-member exchange reflecting the efficacy of the work, carried out by team members within the group, shows willingness of the employees to help team members and share their ideas, and also the situation of being supported and information acquisition in return. In other words, team-member exchange represents the reciprocity between an employee and team members (Seers, 1989). Moreover, team-member exchange reflects the social exchange relations within the team (Liao, Yang, Wang, Drown and Shi, 2013).

Team-member exchange aims to reduce the hierarchical difference between team members and the tendency to work individually, to encourage team work and to create mutual commitment between team members. Furthermore, team-member exchange enhances development of cooperation between team members and increase of team efficacy (Tse, Dasborough and Ashkanasy, 2005). When high-quality team-member exchange is realised, expectations of the team members are met and a high sense of mutuality occurs. Moreover, recognition, appreciation, stimulation, mutual respect and trust are created between team members at high levels. Accordingly, development of resource and support exchange can be possible between the team members towards increasing the performance. In such a case, individuals become more willing to achieve the targets together with the team. When low-quality team-member exchange occurs, inconsistency occurs among team members with relation to expectations and fulfilment. In addition, lack of respect, trust and team cooperation occurs among team members. Hence, the exchange required for fulfilment of team-related tasks is realised at limited levels. In such a case, the individuals become less willing to achieve the targets together with the team (Chen, 2018; Liden, Wayne and Sparroweet, 2000; Love and Forret, 2008; Tse, et al., 2005).

Tse and Dasborough (2008) divide team-member exchange into two categories as task-oriented exchange and relation-oriented exchange. Task-oriented exchange refers to the share of ideas, knowledge and experiences between team members. Relation-oriented exchange includes elements such as help, support, values, sincerity and friendship among team members. Tse, 
Dasborough and Ashkanasyet (2008) state that limited number of task-oriented exchanges occurs in low-quality team-member exchange, and both task-oriented and relation-oriented exchanges occur in high-quality team-member exchange.

High-quality team-member exchange has positive impacts at individual, team and organizational levels on certain elements such as knowledge sharing, individual creativity (Chae et al., 2015), innovative work behaviour (Ghosh et al., 2019), job satisfaction, job performance (Seers, 1989), work engagement (Liao et al., 2013), voice behaviour, creative work involvement (Shih and Wijaya, 2017), group cohesiveness, co-worker satisfaction, team identification (Tse, et al., 2005), team commitment, intention to share knowledge, team performance (Liu et al., 2011), and organizational citizenship behaviour (Love and Forret, 2008).

Lin (2007, p. 315) defines knowledge sharing as "a social interaction culture including mutual exchange of knowledge, experiences and skills owned by the employees within the organization". Ipe (2003, p. 341) defines knowledge sharing as "a process in which knowledge of an individual is transformed into a form that can be understood, internalized and used by other individuals." Knowledge sharing is realized by means of formal and informal channels. While formal channels are referred to as "goal-oriented learning channels", informal channels are referred to as "relational learning channels". Formal channels include transmission of the knowledge in the organization to the employees by means of technology-based communication systems. In informal channels, on the other hand, the individuals engage in mutual interaction depending upon the communication, trust, respect and friendship between them, and as a result, knowledge sharing occurs as a natural process (Bartol and Srivastava, 2002; Ipe, 2003).

Organizational knowledge is accepted as the most important component of organizational learning. In this context, knowledge sharing between the individuals contributes not only to individual learning but also to organizational learning (Andrews and Delahaye, 2000). As knowledge sharing contains knowledge distribution and knowledge acquisition among the individuals, it provides contribution to the organizational learning at significant levels. Furthermore, knowledge sharing behavior of the individuals enables distribution of knowledge within the organization and accordingly, knowledge is acquired by other individuals. Hence, the knowledge sharing between individuals results in individual learning and makes contribution to organizational learning (Ipe, 2003). In other words, employees' learning new knowledge and sharing already learned ones or available ones within the organization enhance organizational learning and carry the business up to a competitive position (Gagne, 2009).

Businesses need to be innovative in order to survive and gain a competitive advantage. In order to be innovative, the businesses should benefit from the tacit knowledge of the employees and use explicit knowledge available in the organization in an effective manner. In other words, inclusion of both implicit and tacit knowledge sharing by knowledge sharing practices is significant for the success of the innovation. Therefore, a business encouraging knowledge sharing can create new ideas and develop new business opportunities and accordingly it can carry out innovation activities (Wang and Wang, 2012). Furthermore, knowledge sharing enabling for improvements in innovation activities is an integral part of learning activities in an organization. In addition, the value of the knowledge shared by the employees directly affects decision-making mechanism of the organization. Creation of effective knowledge sharing within the organization ensures increase in efficiency, decrease in training costs and reduction of risks resulting from uncertainty (Düger, 2021). In addition, knowledge sharing may cause conflicts of interest between the employees. Therefore, the organizations are in search of effective methods, means or systems in order to overcome the factors preventing knowledge sharing. Such means or systems can provide effective sharing of the knowledge by the employees and can improve innovation performance ( $\mathrm{Li}$ et al., 2015). 
Support of knowledge sharing by team-member exchange between the individuals can only happen when a high-quality exchange occurs. In a strong team-member exchange climate, the employees may be more eager to respond to their teammates within the framework of social exchange; on the other hand, in a weak team-member exchange, the perception of low-level exchange by the employees may result in low-level social exchange. Therefore, quality of team-member exchange is directly related to knowledge sharing behaviour of the employees (Liu et al. 2011: 277).

The knowledge can create a synergy only when it is shared with team members and transferred from one person to another. Accordingly, it is achieved to integrate the knowledge owned by the individuals and to transform it into a value. Hence, knowledge sharing can increase and improve collective knowledge (Cabrera et al., 2006; Liu et al. 2011). In this context, it is required to examine the factors stimulating or improving intra-team knowledge sharing. Furthermore, it can be beneficial to examine the knowledge sharing at team level as it generally occurs between the employees within a team (Wu, Hsu and Yeh, 2007).

Thus, the following hypothesis is proposed:

$\mathrm{H}_{1}$ : Team-member exchange is positively related to intra-team knowledge sharing.

\subsection{Role of Intra-Team Trust and Psychological Ownership}

Recently, efficiency, performance, innovation and competitive power have become of great importance for organizations to continue their business, and such situation has increased the significance of teamwork. In addition, as hierarchical levels decrease and team work comes into prominence in the organizations, coordinated working, more cooperative approaches, emphasizing responsibility sharing and inclusion of employees in decision-making process, have started to be adopted instead of traditional manner of rule (Costa, 2003). Together with the increase in popularity of teamwork in organizations, trust, which constitutes the building block of teamwork, comes into prominence (Politis, 2003).

Trust has a universal definition. Many researchers have handled trust in different points of view and put forward different definitions. In general, trust can be defined as "faith in the trustworthy intention of others" (Cook and Wall, 1980, p. 40). In organizational terms, interpersonal trust can be defined as "the extent to which a person is confident in and willing to act on the basis of the words, actions and decisions of another" (McAllister, 1995, p. 25). In other words, interpersonal trust is defined as a psychological state reflecting positive expectations with relation to the actions of other employees (De Jong and Elfring, 2010).

Trust considered as a critical element in the organizations is a significant determinant of interpersonal and intra-team relations. In an environment where there is no trust, cooperation between individuals do not occur and approach of being a team is not developed (Costa, 2003). Trust established within the team positively affects working attitudes and behaviors of the employees and provides conditions required for realization of high team performance (Dirks and Ferrin, 2001). Trust affects the team performance in a positive manner as it increases the efforts of employees towards team success, their commitment and willingness to work in cooperation (Mach and Baruch, 2015). Intra-team trust contributes to the performance by means of ensuring efficient and effective fulfilment of key tasks. As a result of provision of confidence by the employees to team members and effective response of other members to such confidence, team members spend less time to protect themselves. Such situation encourages team members to show more effort to fulfil their tasks (Grossman and Feitosa, 2018).

The individuals have to feel confident in order to trust team members that they will not cause any harm to their individual interests (DeOrtentiis et al., 2013). The environment of trust to be created within the team causes team members to act more transparently and to be more participative in terms of knowledge, and facilitates distribution of the knowledge within the team. Moreover, the 
value of the shared knowledge may differ according to reliability, confidence and helpfulness of the person sharing the knowledge (Penarroja, Orengo, Zornoza, Sánchez and Ripollet, 2015). Trust of the employees in team members and managers ensures creation and share of new knowledge within the organization; such situation can increase organizational skills and performance (Politis, 2003). As a result, it is thought that intra-team trust strengthens the relation between team-member exchange and intra-team knowledge sharing.

Pierce, Kostova and Dirks (2001, p. 299), have handled psychological ownership as "an attitude including both emotional and cognitive aspects", and defined psychological ownership as "the state in which the individual feel a material or moral element by owning it". Psychological ownership reflects the awareness, thoughts and beliefs of an individual with relation to owning anything (Pierce, Kostova and Dirks, 2003). Furby (1991) has stated that the psychology of owning reflects the result of three fundamental states of the individual; positive attitudes towards the target, improved personality and sense of responsibility. Pierce et al. (2001) assert that the psychological ownership meets efficacy, self-identity and sense of belonging needs of the individuals. In addition, Avey, Avolio, Crossley and Luthans (2009) have stated that there are three dimensions explaining psychological ownership, which are sense of belonging, self-identity and selfdefinition.

Psychological sense of ownership of the individuals may occur independently from the state of owning something in legal terms. In other words, in creation of sense of psychological ownership, legal ownership is an important element but it is not indispensable; most of the individuals may feel sense of psychological ownership even when they do not own something legally (Van Dyne and Pierce, 2004). In addition, psychological ownership is divided into two as organization-based and work-based psychological ownerships. Organization-based ownership refers to adoption of the establishment/organization by the individual, while work-based psychological ownership refers to adoption of work by the individual (Mustafa, Ramos and Man, 2015).

Psychological ownership may cause individuals to display extra role behaviors such as helping other employees, being voluntary for certain tasks and guiding new employees. In other words, the sense of ownership may support the employees for taking voluntary actions that will be beneficial for the organization. Psychological ownership in the organizations results in more time and energy spent by the employees to be beneficial for the organization by means of acting with the sense of responsibility. In addition, psychological ownership may cause the employees to display conscientious role behaviors and show high-level working performance (Van Dyne and Pierce, 2004).

As a result of high-level psychological ownership by the employees, the employees may show more commitment towards the organization, develop positive attitudes, consider themselves as a valuable component of the organization and display higher performance for the success of the organization. Moreover, the employees having high level of psychological ownership consider the job as their own job, attach importance to the works and the organization, and share their knowledge with the other employees and the organization devotedly (Zhang, Liu, Zhang, Xu and Cheung, 2021). As a result of psychological ownership by the employees, altruist behaviors may occur (Pierce et al., 2001). Such a situation makes employees contribute to the organization by means of exhibiting behaviors such as knowledge sharing.

Individuals with sense of psychological ownership may display protective or unstaid behaviors. If the individuals think that they will add value to the organization or that the organization will improve, they may tend to display the behavior of sharing their knowledge with other employees or the organization. In addition, when the individual notices a violation with relation to the things towards which he/she feels psychological ownership, he/she may display protective behaviors. 
The individual acting protective may hide knowledge from other employees in order to preserve the stability and protect himself/herself from the change (Avey et al., 2009).

As a result of all these discussions, the following hypotheses are proposed:

$\mathrm{H}_{2}$ : Intra-team trust is positively related to intra-team knowledge sharing.

$\mathrm{H}_{3}$ : Psychological ownership is positively related to intra-team knowledge sharing.

$\mathrm{H}_{4}$ : Intra-team trust moderates the relationship between team-member exchange and intra-team knowledge sharing.

$\mathrm{H}_{5}$ : Psychological ownership moderates the relationship between team-member exchange and intra-team knowledge sharing.

Figure 1: Research Model

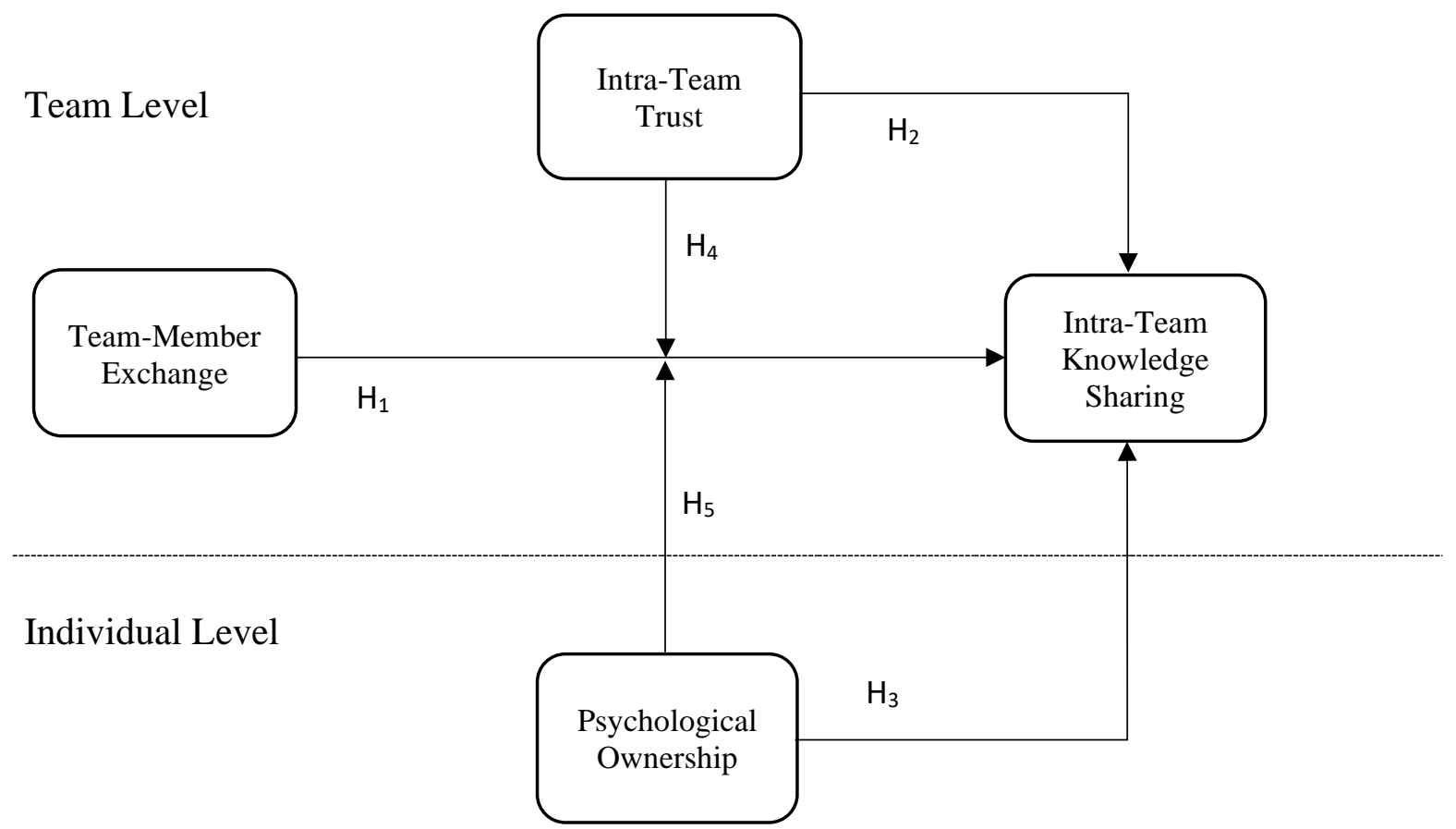

\section{Research Design and Method}

In this part of the study, information about the purpose, scope, data collection and analysis method of the research is given. Before starting the research, permission was obtained from the Social and Human Sciences Scientific Research and Publication Ethics Committee of Kutahya Dumlupinar University and the research was ethically approved by the decision dated 21.05.2020 and numbered 2020/05.

\subsection{Purpose, Scope and Method of the Research}

The aim of this study to measure the effect of team-member exchange on the intra-team knowledge sharing and to empirically explore the role of intra-team trust and psychological ownership in this relationship. A company operating in the textile, service, and manufacturing sectors in Istanbul was chosen as the main mass. Focused on 450 white-collar employees employed by the company. In this context, 250 questionnaires have been distributed to white-collar employees by hand and online using the convenience sampling method in June-December 2020 period. 179 (72\%) admissible questionnaire forms have been collected. The questionnaires consist of two parts; in the first part, there are 6 statements about determining demographic variables, and in the second 
part, there are 29 statements about team-member exchange, knowledge sharing, intra-team trust, and psychological ownership scales.

\subsection{Data Collection and Analysis}

The data required for the research were obtained by the survey method. In the research, a total of four scales, consisting of team-member exchange, knowledge sharing, intra-team trust, and psychological ownership, were used. The team-member exchange scale, which consists of a single dimension and 10 statements, developed by Seers (1989) was used. The knowledge-sharing process scale, which consists of two sub-dimensions as knowledge donating and knowledge collecting, and 7 statements, developed by Lin (2007) was used. The intra-team trust scale, which consists of a single dimension and 5 statements, developed by De Jong and Elfring (2010) was used. The psychological ownership scale, which consists of a single dimension and 7 statements, developed by Van Dyne and Pierce (2004) was used. The 5-point Likert type rating scale $(1=$ Strongly Disagree, $2=$ Disagree, $3=$ Neither Agree $/$ Neither Disagree, $4=$ Agree $5=$ Totally Agree) has been used, in order to measure the statements used in the scales. Exploratory and confirmatory factor analysis was performed using the data through the questionnaire, AMOS, SPSS program, and Process Macro (Hayes, 2013). Correlation analysis was conducted to reveal the relationship among variables. In line with the research model, regression analysis to test the relationship among variables, and analysis within the framework of Hayes' Model 2 to measure moderating effects have been performed.

\section{Research Findings}

In line with the purpose of the study, descriptive statistical analyzes by frequency and percentage were used to determine the demographic characteristics of the participants. In addition, in order to test the research hypotheses, exploratory and confirmatory factor analysis, correlation, multiple linear regression, and Hayes' analysis of measuring the moderating effect were used.

\subsection{Demographic Findings}

First of all, the demographic characteristics of the participants were examined in the study. The demographic characteristics of 169 white-collar workers participating in the; $34.1 \%$ are female, $65.9 \%$ are male, $61.5 \%$ of them are single and $38.5 \%$ are married. $39.7 \%$ of the employees are in the $18-25$ age group, $20.1 \%$ in the $26-30$ age group, $26.8 \%$ in the $31-39$ age group, $12.3 \%$ in the 40-54 age group, and $1.1 \%$ in the 55 age and above. $2.2 \%$ of the participants have primary education degree, $12.3 \%$ high school degree, $10.6 \%$ associate degree, $62.1 \%$ bachelor's degree, and $12.8 \%$ master's degree. In addition, $20.7 \%$ of the participants have a working period of less than 1 year, $44.1 \%$ 1-5 years, $10.6 \%$ 6-10 years, $21.8 \% 11-20$ years, and $2.8 \%$ more than 20 years. $42.5 \%$ of the participants have 3,000 TL and less, $17.3 \% 3,001 \mathrm{TL}-4,000 \mathrm{TL}, 21.2 \% 4,001 \mathrm{TL}-$ 5,000 TL, 5\% 5,001 TL - 6,000 TL, and 14\% 6,000 TL and above income. See the details in Table 1. 
Table 1: Demographic Characteristics of Participants

\begin{tabular}{llcc}
\hline Variables & Category & Frequency & \% \\
\hline \multirow{2}{*}{ Gender } & Female & 61 & 34.1 \\
& Male & 118 & 65.9 \\
\hline \multirow{4}{*}{ Age } & $18-25$ & 71 & 39.7 \\
& $26-30$ & 36 & 20.1 \\
& $31-39$ & 48 & 26.8 \\
\multirow{5}{*}{ Work Period } & $40-54$ & 22 & 12.3 \\
& 55 years and older & 2 & 1.1 \\
\hline \multirow{2}{*}{ Marital Status } & Less than 1 year & 37 & 20.7 \\
& $1-5$ & 79 & 44.1 \\
& 6-10 & 19 & 10.6 \\
\multirow{5}{*}{ Education } & $11-20$ & 39 & 21.8 \\
& More than 20 years & 5 & 2.8 \\
\hline \multirow{4}{*}{ Income } & Married & 69 & 38.5 \\
& Single & 110 & 61.5 \\
\hline & Primary School & 4 & 2.2 \\
& High School & 22 & 12.3 \\
& Associate Degree & 19 & 10.6 \\
& Bachelor's Degree & 111 & 62.1 \\
& Master's Degree & 23 & 12.8 \\
\hline
\end{tabular}

\subsection{Reliability, Validity and Factor Analysis Results}

After investigating the demographic characteristics of the participants, the reliability values of the research variables were analyzed. The reliability analysis is aimed to reveal the consistency of the expressions in the scales with each other. Cronbach Alpha coefficient was calculated for reliability analysis. Principal component analysis as a factoring method in order to determine the factor structures of the scales used in the research; Varimax rotation is used as the rotation method. Before exploratory factor analysis, Bartlett's test was used to test the suitability of the data set to factor analysis, and the Kaiser-Meyer-Olkin (KMO) value was calculated to test the sampling competence. In the exploratory factor analysis applied for the 29 items used in the study, it was determined for the exploratory factor load values should be over 0.50 and, for the confirmatory factor analysis over 0.70 .

According to the exploratory factor analysis and confirmatory factor analysis results; 3 items from the team-member exchange scale and 1 item from the psychological ownership scale were excluded from the analysis because they were cross-loaded, had a factor load of less than 0.5 (EFA) and 0.70 (CFA). After the items extracted, the analysis were renewed and the results obtained are given in Table 2.

As a result of the analysis, it was found that KMO values of all scales were between 0.804-0.885; Cronbach Alpha value is between 0.880-0.969; It was determined that the total variance values explained were between 0.58-0.81. It was concluded that the results were sufficient for each item and scale. According to the findings, it was concluded that the data were suitable for factor analysis. It is seen that the factor loads of the items that make up the factors are between 0.6670.944. All these results indicated that the factor structures of all scales are uniformly distributed and reliable (Kalayc1, 2016). 
Table 2: Exploratory Factor Analysis Findings

\begin{tabular}{|c|c|c|c|c|c|}
\hline Variables & Items & $\begin{array}{c}\text { Factor } \\
\text { Loading }\end{array}$ & $\begin{array}{c}\text { Total } \\
\text { Variance } \\
\text { Explained } \\
\end{array}$ & $\begin{array}{c}\text { Cronbach's } \\
\text { Alpha } \\
\text { Value } \\
\end{array}$ & $\begin{array}{c}\text { Kaiser- } \\
\text { Meyer- } \\
\text { Olkin }\end{array}$ \\
\hline \multirow{7}{*}{$\begin{array}{l}\text { Team-Member } \\
\text { Exchange }\end{array}$} & TMX6 & 0.812 & \multirow{7}{*}{$58.71 \%$} & \multirow{7}{*}{0.880} & \multirow{7}{*}{0.885} \\
\hline & TMX4 & 0.799 & & & \\
\hline & TMX5 & 0.793 & & & \\
\hline & TMX8 & 0.770 & & & \\
\hline & TMX7 & 0.767 & & & \\
\hline & TMX9 & 0.748 & & & \\
\hline & TMX3 & 0.667 & & & \\
\hline \multirow{7}{*}{ Knowledge Sharing } & $\mathrm{KC} 2$ & 0.944 & \multirow{7}{*}{$85.1 \%$} & \multirow{7}{*}{0.969} & \multirow{7}{*}{0.843} \\
\hline & $\mathrm{KC} 1$ & 0.942 & & & \\
\hline & $\mathrm{KC} 3$ & 0.915 & & & \\
\hline & $\mathrm{KC} 4$ & 0.855 & & & \\
\hline & KD1 & 0.942 & & & \\
\hline & $\mathrm{KD} 2$ & 0.940 & & & \\
\hline & KD3 & 0.917 & & & \\
\hline \multirow{5}{*}{ Intra-Team Trust } & ITT4 & 0.886 & \multirow{5}{*}{$70.17 \%$} & \multirow{5}{*}{0.884} & \multirow{5}{*}{0.804} \\
\hline & ITT1 & 0.858 & & & \\
\hline & ITT3 & 0.853 & & & \\
\hline & ITT5 & 0.851 & & & \\
\hline & ITT2 & 0.731 & & & \\
\hline \multirow{6}{*}{$\begin{array}{l}\text { Psychological } \\
\text { Ownership }\end{array}$} & PO4 & 0.942 & \multirow{6}{*}{$81.88 \%$} & \multirow{6}{*}{0.953} & \multirow{6}{*}{0.854} \\
\hline & PO1 & 0.942 & & & \\
\hline & PO3 & 0.941 & & & \\
\hline & PO5 & 0.912 & & & \\
\hline & $\mathrm{PO} 2$ & 0.905 & & & \\
\hline & PO7 & 0.776 & & & \\
\hline
\end{tabular}

The Fit index values according to the confirmatory factor analysis results of team-member exchange, knowledge-sharing, intra-team trust, and psychological ownership scales are given in Table 3.

Table 3: Fit Indices for Confirmatory Factor Analysis

\begin{tabular}{lcccccc}
\hline Variables & $\left(\mathbf{X}^{2} / \mathbf{s d}\right)$ & NFI & CFI & RMSEA & GFI & RMR \\
\hline Team-Member Exchange & 2.298 & 0.951 & 0.972 & 0.085 & 0.955 & 0.015 \\
\hline Knowledge Sharing & 3.070 & 0.988 & 0.992 & 0.098 & 0.966 & 0.007 \\
\hline Intra-Team Trust & 3.685 & 0.980 & 0.985 & 0.099 & 0.976 & 0.009 \\
\hline Psychological Ownership & 4.610 & 0.979 & 0.983 & 0.099 & 0.956 & 0.022 \\
\hline
\end{tabular}

As a result of the confirmatory factor analysis, it is observed that the goodness of fit values for the scales are in the excellent fit value range (Meydan and Şeşen, 2015). Moreover, as a result of the confirmatory factor analysis, it is demonstrated that the $p$ values indicating the significance values are $\mathrm{p}<0.01$ and all $\mathrm{t}$ values over 2.56 . These results prove that the scales are statistically significant (Çokluk, Şekercioğlu and Büyüköztürk, 2016).

\subsection{Correlation and Regression Analysis Results}

After the exploratory and confirmatory factor analysis, correlation analysis was applied for the variables used in the study. According to the result of the correlation analysis, there is a positive and significant relationship among team-member exchange, knowledge sharing, intra-team trust, and psychological ownership at $\mathrm{p}<0.01$ significance level. The detailed findings from the correlation analysis are given in Table 4. 
Table 4: Correlations, Means, and Standard Deviations of Variables

\begin{tabular}{llccccc}
\hline & Variables & Mean & SD & $\mathbf{1}$ & $\mathbf{2}$ & $\mathbf{3}$ \\
\hline $\mathbf{1}$ & Team-Member Exchange & 4.1173 & 0.4965 & 1 & & \\
\hline $\mathbf{2}$ & Knowledge Sharing & 4.1464 & 0.4794 & $0.401 * *$ & 1 & \\
\hline $\mathbf{3}$ & Intra-Team Trust & 4.0491 & 0.6079 & $0.282^{* *}$ & $0.609 * *$ & 1 \\
\hline $\mathbf{4}$ & Psychological Ownership & 4.0851 & 0.6070 & $0.282^{* *}$ & $0.647 * *$ & $0.419 * *$ \\
\hline ***ignificant at $p<0.01$ & & & & &
\end{tabular}

After determining the relationships among variables with correlation analysis, regression analysis was applied to explain the cause-effect relationship among the variables used and to test the research hypotheses. The linear regression analysis results showing the direct effect among variables are given in Table 5.

Table 5: Regression Analysis Result (The Dependent Variable: Knowledge Sharing)

\begin{tabular}{lcccccc}
\hline Variables & Coefficient & $\boldsymbol{\beta}$ & $\boldsymbol{t}$ & $\boldsymbol{p}$ & Tolerance & VIF \\
\hline Constant & 1.028 & - & 4.514 & 0.000 & - & - \\
\hline Team-Member Exchange & 0.164 & 0.170 & 3.288 & 0.001 & 0.888 & 1.126 \\
\hline Intra-Team Trust & 0.297 & 0.376 & 6.868 & 0.000 & 0.795 & 1.257 \\
\hline Psychological Ownership & 0.304 & 0.441 & 8.063 & 0.000 & 0.795 & 1.257 \\
\hline
\end{tabular}

$R^{2}: 0.583 ;$ Adjusted $R^{2}: 0.576 ; F: 81.477 ; p<0.001$

The results of the linear regression analysis and linearity fit of the model $(\mathrm{F}=81.477 ; \mathrm{p}<0.001)$ indicate that the regression model is significant. Besides, to understand whether there is a multicollinearity problem or not among variables, Tolerance and VIF values were also analyzed. According to Hair et al. (1995) state that in case the tolerance value has large and the VIF value has a small value, the probability of multicollinearity is lower among variables. As a result of the analysis, the obtained Tolerance and VIF values indicated that there is no multicollinearity problem among variables.

According to the regression analysis results; team-member exchange $(\beta=0.170 ; t=3.288 ; p<0.001)$, intra-team trust $(\beta=0.376 ; \mathrm{t}=6.868 ; \mathrm{p}<0.001)$, and psychological ownership $(\beta=0.441 ; \mathrm{t}=8.063$; $\mathrm{p}<0.001)$ have a positive and significant effect on knowledge sharing. According to these results, $\mathrm{H}_{1}, \mathrm{H}_{2}$, and $\mathrm{H}_{3}$ hypotheses were accepted.

In order to determine the moderating effect of intra-team trust and psychological ownership in the relationship between team-member exchange and knowledge, regression analysis was performed using the Process Macro (Model-2) developed by Hayes (2013). The detailed results of the analysis are given in Table 6. 
Table 6: Moderating Effect of Intra-Team Trust and Psychological Ownership

\begin{tabular}{|c|c|c|c|c|c|c|}
\hline Variables & Coefficient & SE & $t$ & $p$ & $\begin{array}{l}\mathbf{L L} \\
95 \% \mathbf{C I}\end{array}$ & $\begin{array}{c}\text { UL } \\
95 \% \\
\text { CI } \\
\end{array}$ \\
\hline $\begin{array}{l}\text { Interaction term of Team- } \\
\text { Member Exchange X Intra- } \\
\text { Team Trust }\end{array}$ & -0.2186 & 0.086 & -2.5157 & 0.012 & -0.3901 & -0.0471 \\
\hline $\begin{array}{l}\text { Interaction term of Team- } \\
\text { Member Exchange X } \\
\text { Psychological Ownership }\end{array}$ & 0.3502 & 0.074 & 4.7066 & 0.000 & 0.2033 & 0.4970 \\
\hline \multicolumn{7}{|c|}{$\begin{array}{c}\text { Conditional effect of team-member exchange on knowledge sharing at low and high values of } \\
\text { intra-team trust }\end{array}$} \\
\hline Low & 0.3344 & 0.065 & 5.150 & 0.000 & 0.2063 & 0.4626 \\
\hline High & 0.1069 & 0.073 & 1.4727 & 0.143 & -0.0364 & 0.2502 \\
\hline \multirow{2}{*}{\multicolumn{2}{|c|}{$\mathbf{R}^{2}$ increase due to interaction }} & $\Delta \mathbf{R}^{2}$ & $\mathbf{F}$ & $p$ & & \\
\hline & & 0.0135 & 6.3286 & 0.012 & & \\
\hline
\end{tabular}

Conditional effect of team-member exchange on knowledge sharing at low and high values of psychological ownership

\begin{tabular}{|c|c|c|c|c|c|c|}
\hline Low & 0.0273 & 0.082 & 0.332 & 0.740 & -0.135 & 0.189 \\
\hline High & 0.4093 & 0.102 & 4.021 & 0.000 & 0.208 & 0.610 \\
\hline \multicolumn{2}{|c|}{$\mathbf{R}^{2}$ increase due to interaction } & $\Delta \mathbf{R}^{2}$ & $\mathbf{F}$ & $p$ & & \\
\hline & & 0.0474 & 22.152 & 0.000 & & \\
\hline & $\mathbf{R}$ & $\mathbf{R}^{2}$ & $\mathbf{F}$ & $p$ & & \\
\hline & 0.794 & 0.630 & 58.958 & 0.000 & & \\
\hline \multicolumn{2}{|c|}{ Total $R^{2}$ increase due to double interaction } & $\Delta \mathbf{R}^{2}$ & $\mathbf{F}$ & $p$ & & \\
\hline & & 0.0474 & 11.088 & 0.000 & & \\
\hline
\end{tabular}

The interaction term of team-member exchange $\mathrm{x}$ intra-team trust $(B=-0.217 ; \mathrm{p}<0.05)$ is significant. Also, the interaction term of team-member exchange $\mathrm{x}$ psychological ownership $(B=$ $0.350 ; \mathrm{p}<0.01)$ is significant. Summary values of the double model for moderating effect $\mathrm{R}^{2}=0.630 ; \mathrm{F}=58.958 ; \mathrm{p}<0.01$ appear to be significant. As a result of moderating effects, the ratio of team-member exchange to explain knowledge sharing increased from 58\% to $63 \%$ (See Table 5). The adjusted $\mathrm{R}^{2}$ value increased by $4.7 \%$ at the $\mathrm{p}<0.01$ significance level with the moderating effects of intra-team trust and psychological ownership. It has been concluded that intra-team trust and psychological ownership have moderator roles in the effect of team-member exchange on knowledge sharing in conclusion. Accordingly, the $\mathrm{H}_{4}$ and $\mathrm{H}_{5}$ hypotheses were accepted.

Two graphs were obtained using the ModGraph-I program developed by Jose (2013) to better understand the moderating effect of intra-team trust and psychological ownership at different levels. The moderating effects are given in cases where intra-team trust has low and high values in Graph 1. When intra-team trust is at a low level, moderating effect is significant $(B=0.334$; 
$\mathrm{t}=5.15 ; \mathrm{p}<0.01)$ but it is not significant at a high level $(B=0.107 ; \mathrm{p}=0.143 ; \mathrm{t}=1.473)$. The result indicated that in case of intra-team trust increases, the moderating effect continues to increase with a decrease. The moderating effects are given in cases where psychological ownership has low and high values in Graph 2. When psychological ownership is at a low level, moderating effect is not significant $(B=0.027 ; \mathrm{t}=0.332 ; \mathrm{p}=0.740)$, however it is significant at a high level $(B=0.409 ; \mathrm{p}<0.01$; $\mathrm{t}=4.021)$. The result indicated that when psychological ownership increases, the moderating effect increases accordingly.

Graph 1: Interaction Level of Intra-Team Trust as a Moderator

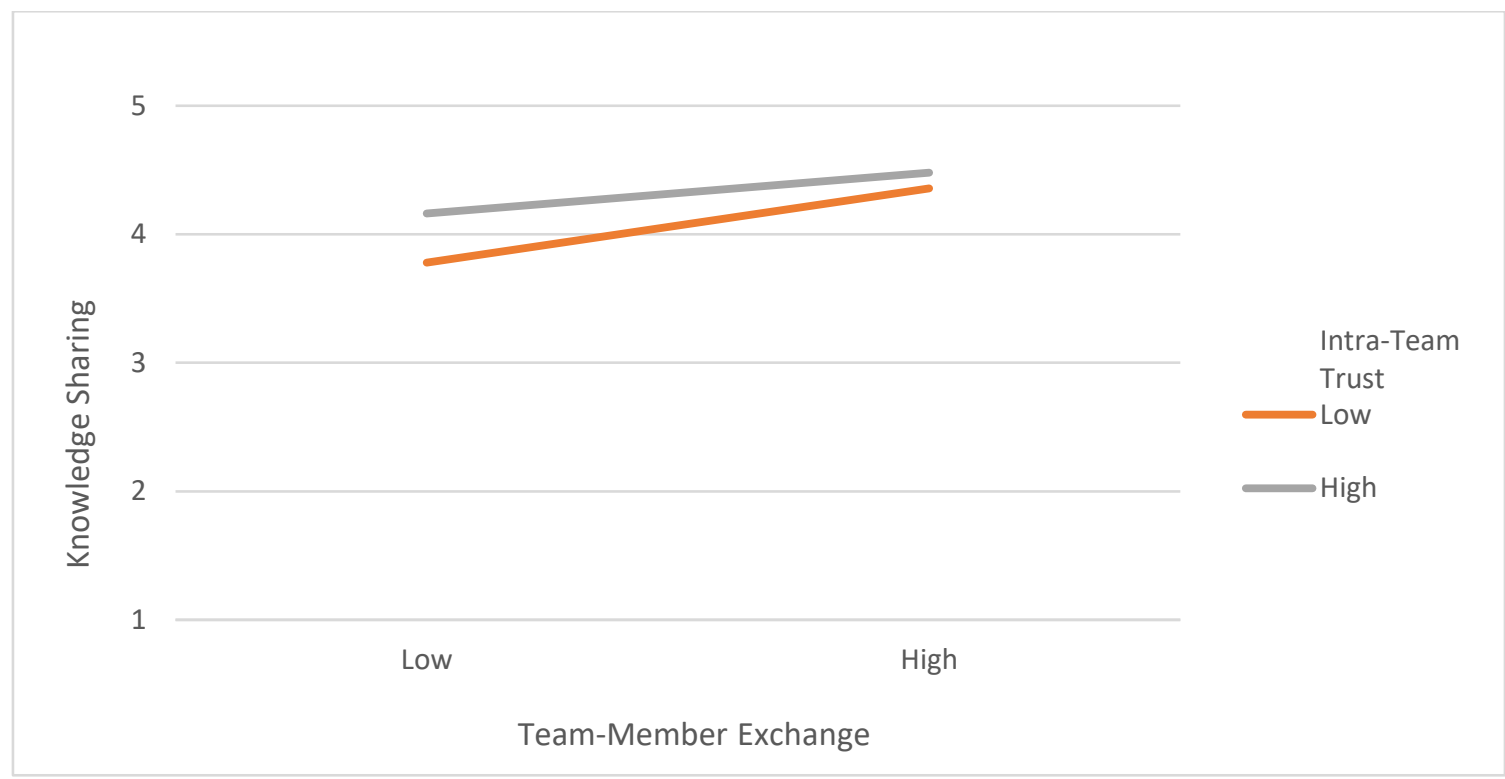

Graph 2: Interaction Level of Psychological Ownership as a Moderator

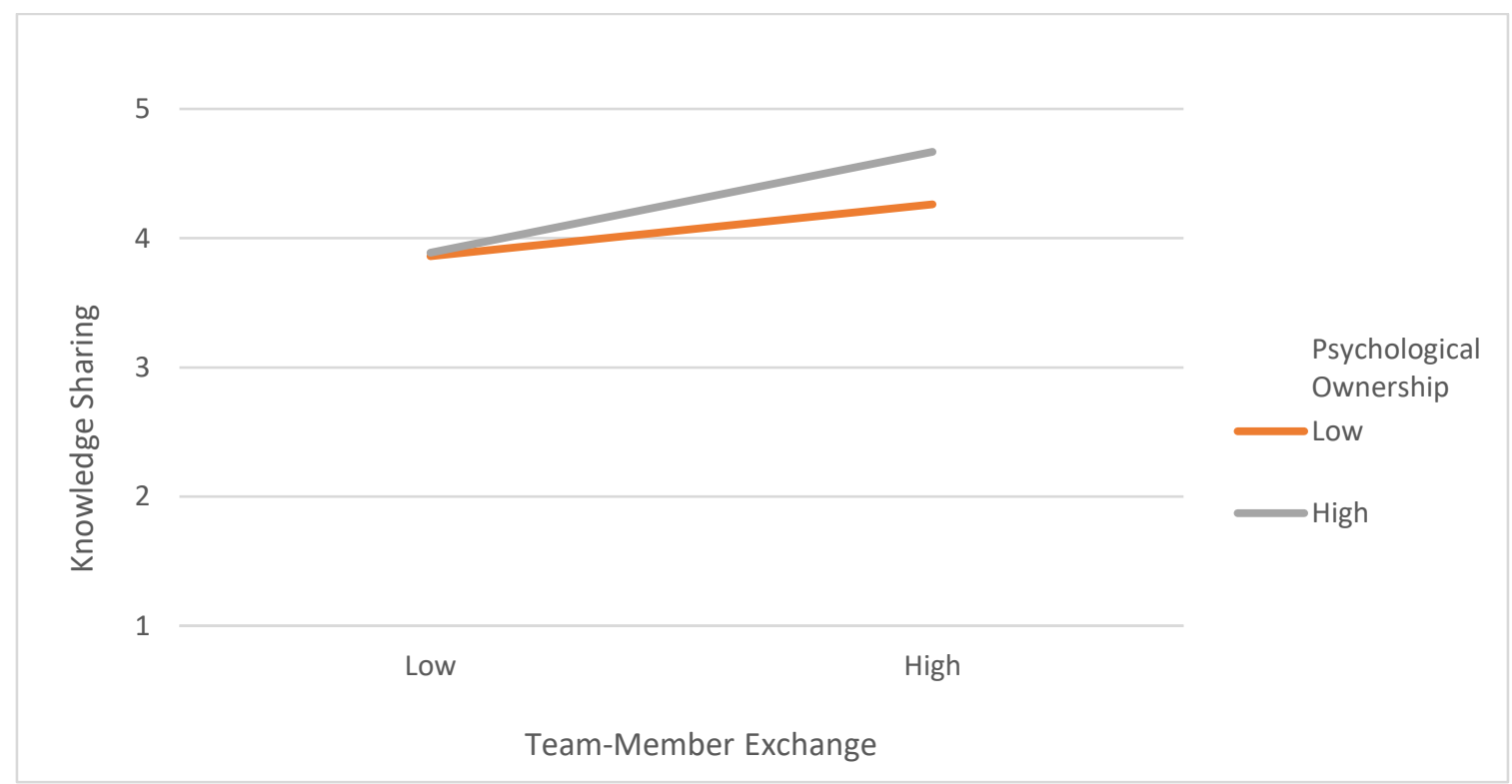

\section{Discussion}

In this study, it is aimed to measure the impact of team-member exchange on intra-team knowledge sharing and to discover empirically the role of intra-team trust and psychological ownership in such relation. According to the result of the research, team-member exchange has a positive impact on intra-team knowledge sharing. Such result shows similarity with the results of the research 
made by Chae et al. (2015) and Liu et al. (2011). Chen (2018) states that realization of high-quality team-member exchange positively affects mutual support, knowledge sharing and innovation processes among the individuals. In this context, realization of mutual exchange between the team members increases interaction between the employees and accordingly harmonization, cooperation and team spirit emerge among the employees. The exchange between the employees mutually includes many elements such as cooperation, supporting, satisfaction of expectations and fulfilment of tasks. The increase in the quality of the exchange between team employees makes the employees display devoted behaviors and show more effort for the success of the team and the organization. In such a case, the employees may tend to share the knowledge, experience and expertise they own with other team members.

It has been concluded that intra-team trust and psychological ownership have positive impact on intra-team knowledge sharing. Such result shows similarity with the results of certain studies included in the literature (Al-Alawi, Al-Marzooqi and Mohammed 2007; Chen and Hung, 2010; Pittino, Martinez, Chirico and Galvan, 2018). Trust is not limited to the relation between the leader and the employee; it also contains the interaction between the team members (Dirks and Ferrin, 2001). Intra-team trust has a significant impact both on individual performance and team performance (Mach and Baruch, 2015). Problems encountered in the organization with relation to working systems based on cooperation can be solved especially by means of the trust established between the employees. In addition, the trust established between the employees affects knowledge sharing significantly (Politis, 2003). Creation of environment of trust within the organization positively affects the motivation of employees and facilitates display of extra role behaviors by them. In this scope, trust is considered as an important driving force affecting knowledge sharing behaviors of the employees. When employees own the organization psychologically and consider it as their own business, important changes will certainly occur in their attitudes, behaviors and points of view. Employees with such sense of psychological ownership consider the success of the organization as their own success and accordingly they show their best effort.

Furthermore, it has been concluded that intra-team trust and psychological ownership play a moderating role in the relation between team-member exchange and intra-team knowledge sharing. Such empiric result demonstrates that intra-team trust and psychological ownership increase the strength of the relation between related variables. Knowledge sharing of the employees is generally an extra role behavior triggered by strong internal motivation (Lin, 2007). In this context, motivation of the team members with relation to knowledge sharing improves on the basis of quality of team-member exchange, trust and psychological ownership.

\section{Conclusion}

According to the results of the research, team-member exchange, intra-team trust and psychological ownership are important premises of knowledge sharing. Moreover, findings show that intra-team trust and psychological ownership strengthens the relation between team-member exchange and intra-team knowledge sharing.

\subsection{Implications}

Knowledge sharing by the employees directly affects the success of the organisation and its potential to make innovations. In this context, factors that will motivate the employees for knowledge sharing should be examined. In the studies included in the literature, knowledge sharing is addressed at individual or organisational levels. In this study, knowledge sharing has been handled at team level, which is different from the other studies in the literature.

The team considered as the smallest unit of the organisation affects the performance and success of the organisation significantly. The quality of team-member exchange has an important role in 
formation of team spirit and common goals. Team-member exchange includes a social exchange, which is beyond an economic exchange. Therefore, the exchange occurring between the team members may result in an increase in the interaction between the employees and a raise in emotional commitment. Accordingly, more sincere relations can be developed between the employees. In such an environment, support of employees and transfer of knowledge and experiences are natural results. In addition, existence of an environment of trust supports such situation significantly. At this point, significant responsibilities fall upon the managers and team leaders. The managers act as a role model for other employees and create an environment supporting cooperation, trust and knowledge sharing. Moreover, the managers should ensure adoption of the organisation and work by the employees by displaying participative approaches in decisions related to the organisation or the team.

\subsection{Limitations and Future Directions}

In this study, data have been collected by means of questionnaires; however, in such kind of a data collection method, personal perceptions and prejudices of the individuals may come to the forefront and the individuals can avoid sharing their actual thoughts considering that the knowledge they provide may be examined by the managers of the establishment. In addition, current results of the research may differ in employees of other companies or in different sectors. Therefore, one should be careful while making generalisation with relation to the results of the research. It is recommended to carry out future studies within a broader sample and to focus on the sectors in which teamwork is of great importance. Furthermore, it is recommended to use qualitative and quantitative methods together to decrease personal perceptions and prejudices. In future studies, it is thought that examination of impacts of managers, job quality, working environment and organisational culture on quality of team-member exchange can provide significant contribution to the literature. In addition, it is recommended to carry out studies that address motivational sources affecting knowledge sharing behaviours within the framework of personality traits and cultural dimensions.

\section{References}

Al-Alawi, A.L., Al-Marzooqi, N.Y. \& Mohammed, Y.F. (2007). Organizational culture and knowledge sharing: critical success factors. Journal of Knowledge Management, 11(2), 2242.

Andrews, K. M. \& Delahaye, B. L. (2000). Influences on knowledge processes in organizational learning: The psychological filter. Journal of Management Studies, 37(6), 797-810.

Avey, J. B., Avolio, B. J., Crossley, C. D., \& Luthans, F. (2009). Psychological ownership: Theoretical extensions, measurement and relation to work outcomes. Journal of Organizational Behavior, 30(2), 173-191.

Bartol, K. M. \& Srivastava, A. (2002). Encouraging knowledge sharing: The role of organizational reward systems. Journal of Leadership \& Organizational Studies, 9(1): 64-77.

Cabrera, A., Collins, W. \& Salgado, J. (2006). Determinants of individual engagement in knowledge sharing. International Journal of Human Resource Management, 17(2), 245264.

Chae, S., Seo, Y. \& Lee, K.C. (2015). Effects of task complexity on individual creativity through knowledge interaction: A comparison of temporary and permanent teams. Computers in Human Behavior, 42,138-148.

Chen, C.-J. \& Hung, S.-W. (2010). To give or to receive? Factors influencing members' knowledge sharing and community promotion in professional virtual communities. Information \& Management, 47(4), 226-236. 
Chen, Z. (2018). A literature review of team-member exchange and prospects. Journal of Service Science and Management, 11, 433-454.

Çokluk, Ö., Şekercioğlu, G. \& Büyüköztürk, Ş. (2016). Sosyal bilimler için çok değişkenli istatistik SPSS ve LISREL uygulamaları, (4. Bask1), Ankara: Pegem Akademi Yayınları.

Cook, J. \& Wall, T. (1980). New work attitude measures of trust, organizational commitment and personal need non-fulfilment. Journal of Occupational Psychology, 53(1), 39-52.

Costa, A.C. (2003). Work team trust and effectiveness. Personnel Review, 32(5), 605-622.

Dansereau, F., Graen, G. \& Haga, W.J. (1975). A vertical dyad linkage approach to leadership within formal organizations: a longitudinal investigation of the role making process. Organizational Behavior and Human Performance, 13(1), 46-78.

De Jong, B. A. \& Elfring, T. (2010). How does trust affect the performance of ongoing teams? the mediating role of reflexivity, monitoring, and effort. Academy of Management Journal, 53(3), 535-549.

DeOrtentiis, P. S., Summers, J. K., Ammeter, A. P., Douglas, C. \& Ferris, G. R. (2013). Cohesion and satisfaction as mediators of the team trust - team effectiveness relationship: An interdependence theory perspective. Career Development International, 18(5), 521-543.

Dirks, K.T. \& Ferrin, D.L. (2001). The role of trust in organizational settings. Organization Science, 12(4), 450-467.

Düger, Y. S. (2021). Etik liderlik ile bilgi paylaşımı arasındaki ilişki: sistematik bir inceleme. Alanya Akademik Baklş, 5(2), 619-645.

Fan, Z.-P., Suo, W.-L., Feng, B. \& Liu, Y. (2011). Trust estimation in a virtual team: A decision support method. Expert Systems with Applications, 38(8), 10240-10251.

Furby, L. (1991). Understanding the psychology of possession and ownership: a personal memoir and appraisal of our progress. Journal of Social Behavior and Personality, 6(6), 457-463.

Gagne, M. (2009). A model of knowledge-sharing motivation. Human Resource Management, 48(4), 571-589.

Ghosh, V., Bharadwaja, M., Yadav, S. \& Kabra, G. (2019). Team-member exchange and innovative work behaviour: The role of psychological empowerment and creative selfefficacy. International Journal of Innovation Science, 11(3), 344-361.

Graen, G. B. \& Uhl-Bien, M. (1995). Relationship-based approach to leadership: Development of leader-member exchange (LMX) theory of leadership over 25 years: Applying a multilevel multi-domain perspective. Leadership Quarterly, 6(2), 219-247.

Grossman, R. \& Feitosa, J. (2018). Team trust over time: Modeling reciprocal and contextual influences in action teams. Human Resource Management Review, 28(4), 395-410.

Hair, J. F., Anderson, R. E., Tatham, R. L. \& Black, W. C. (1995). Multivariate data analysis. Englewood Cliffs, NJ: Prentice-Hall.

Han, G. \& Harms, P. D. (2010). Team identification, trust, and conflict: a mediation model. International Journal of Conflict Management 21(1), 20-43.

Hayes, A. F. (2013). Introduction to mediation, moderation, and conditional process analysis. New York, NY: The Guilford Press.

Ipe, M. (2003). Knowledge sharing in organizations: A conceptual framework. HRM Development Review, 2, 337-359. 
Jose, P.E. (2013). ModGraph-I: A programme to compute cell means for the graphical display of moderational analyses: The internet version, Version 3.0. Victoria University of Wellington, Wellington, New Zealand. Retrieved from https://psychology.victoria.ac.nz/modgraph/

Kalaycı, Ş. (2016). SPSS uygulamalı çok değişkenli istatistik teknikleri, Ankara: Asil Yayınları.

Li, J., Yuan, L., Ning, L. \& Li-Ying, J. (2015). Knowledge sharing and affective commitment: the mediating role of psychological ownership. Journal of Knowledge Management, 19(6), 1146-1166.

Liao, F.Y., Yang, L.Q., Wang, M., Drown, D. \& Shi, J. (2013). Team-member exchange and work engagement: does personality make a difference?. Journal of Business and Psychology, 28(1), 63-77.

Liden, R. C., Wayne, S. J., \& Sparrowe, R. T. (2000). An examination of the mediating role of psychological empowerment on the relations between the job, interpersonal relationships, and work outcomes. Journal of Applied Psychology, 85(3), 407-416.

Lin, H.-F. (2007). Knowledge sharing and firm innovation capability: An empirical study. International Journal of Manpower, 28(3/4), 315-332.

Liu, Y., Keller, R.T. \& Shih, H.-A. (2011). The impact of team-member exchange, differentiation, team commitment, and knowledge sharing on $\mathrm{R} \& \mathrm{D}$ project team performance. $R \& D$ Management, 41(3), 274-287.

Love, M.S. \& Forret, M. (2008). Exchange relationships at work: An examination of the relationship between team-member exchange and supervisor reports of organizational citizenship behavior. Journal of Leadership \& Organizational Studies, 14(4), 342-352.

Mach, M. \& Baruch, Y. (2015). Team performance in cross cultural project teams: The moderated mediation role of consensus, heterogeneity, faultlines and trust. Cross Cultural Management: An International Journal, 22(3), 464-486.

McAllister, D.J. (1995). Affect and cognitive-based trust as foundations for interpersonal cooperation in organizations. Academy of Management Journal, 38(1), 24-59.

Meydan, C. H. \& Şeşen, H. (2015), Yapısal eşitlik modellemesi AMOS uygulamaları, (2. Basım), Ankara: Detay Yayıncılık.

Mustafa, M., Ramos, H.M. \& Man, T.W.Y. (2015). Linking psychological ownership to employee extra-role behaviours in small overseas Chinese family businesses: Does family status matter?. Journal of Entrepreneurship in Emerging Economies, 7(2), 129-147.

Penarroja. V., Orengo. V., Zornoza. A., Sánchez. J. \& Ripoll. P. (2015). How team feedback and team trust influence information processing and learning in virtual teams: A moderated mediation model. Computers in Human Behavior, 48, 9-16.

Pierce, J. L., Kostova, T. \& Dirks, K. T. (2001). Toward a theory of psychological ownership in organizations. Academy of Management Review, 26(2), 298-310.

Pierce, J. L., Kostova, T., \& Dirks, K. T. (2003). The state of psychological ownership: Integrating and extending a century of research. Review of General Psychology, 7(1), 84-107.

Pittino, D., Martinez, A.B., Chirico, F. \& Galvan, R.S. (2018). Psychological ownership, knowledge sharing and entrepreneurial orientation in family firms: The moderating role of governance heterogeneity. Journal of Business Research, 84, 312-326. 
Politis, J.D. (2003). The connection between trust and knowledge management: what are its implications for team performance. Journal of Knowledge Management, 7(5), 55-66.

Seers, A. (1989). Team-member exchange quality: A new construct for role-making research. Organizational Behavior and Human Decision Processes, 43, 118-135.

Shih, H.-A. \& Wijaya, N.H.S. (2017). Team-member exchange, voice behavior, and creative work involvement. International Journal of Manpower, 38(3), 417-431.

Tse, H. H.M., Dasborough, M. T., \& Ashkanasy, N. M. (2005). The role of affect, fairness, and social perception in team member exchange. In The Effect of Affect in Organizational Settings, 1, 143-171.

Tse, H.H.M. \& Dasborough, M.T. (2008). A study of exchange and emotions in team member relationships. Group \& Organization Management, 33(2), 194-215.

Tse, H.H.M., Dasborough, M.T. \& Ashkanasy, N.M. (2008). A multi-level analysis of team climate and interpersonal exchange relationships at work. The Leadership Quarterly, 19(2), 195-211.

Van Dyne, L. \& Pierce, J. L. (2004). Psychological ownership and feelings of possession: three field studies predicting employee attitudes and organizational citizenship behavior. Journal of Organizational Behavior, 25, 439-459.

Wang, Z. \& Wang, N. (2012). Knowledge sharing, innovation and firm performance. Expert Systems with Applications, 39(10), 8899-8908.

Wu, W.-L., Hsu, B.-F. \& Yeh, R.-S. (2007). Fostering the determinants of knowledge transfer: a team-level analysis. Journal of Information Science. 33(3), 326-339.

Yang, I. (2014). What makes an effective team? The role of trust (dis)confirmation in team development. European Management Journal, 32(6), 858-869.

Zhang, Y., Liu, G., Zhang, L., Xu, S., \& Cheung, M. W.-L. (2021). Psychological ownership: a meta-analysis and comparison of multiple forms of attachment in the workplace. Journal of Management, 47(3), 745-770. 